\title{
Into the Loop: The Doomed Reform of Dublin and Solidarity in the New Pact
}

Francesco Maiani"

\section{Introduction}

In ongoing discussions on the reform of the CEAS, solidarity is a key theme. It stands front and centre in the New Pact on Migration and Asy$l_{u m}^{1}$ : after announcing that the approach taken is "human and humane", the quote opening the document stresses that Member States must be able to "rely on the solidarity of our whole European Union".

In describing the need for reform, the Commission does not mince its words: "[ $t]$ here is currently no effective solidarity mechanism in place, and no efficient rule on responsibility". It's a remarkable statement: barely one year ago, the Commission maintained that "[ $t]$ he EU [had] shown tangible and rapid support to Member States under most pressure ${ }^{2 "}$ throughout the crisis. Be that as it may, we have been promised a "fresh start". Thus, President Von der Leyen has announced on the occasion of the 2020 State of the Union Address that "we will abolish the Dublin Regulation", the 2016 Dublin IV Proposal ${ }^{4}$ has been withdrawn, and the Pact proposes a "new solidarity mechanism" connected to "robust and fair management of the external borders" and capped by a new "governance framework".

* Director of the School of Law and Professor at the University of Lausanne.

1 Commission, 'Communication to the European Parliament, the Council, the European Economic and Social Committee and the Committee of the Regions on a New Pact on Migration and Asylum', COM(2020)609.

2 Commission, 'Communication Reporting on the Implementation of the European Agenda on Migration', COM(2019)481.

3 See Alexandra Brzozowski and Sarantis Michalopoulos, 'Mandatory Relocation Still Point Out of Contention in New EU Migration Pact', (Euractiv, 16 September 2020) <www.euractiv.com/section/justice-home-affairs/news/mandatory-relocation -still-point-of-contention-in-new-eu-migration-pact/> accessed 19 November 2021.

4 For analysis see Constantin Hruschka, 'Dublin Is Dead! Long Live Dublin! The 4 May 2016 Proposal of the European Commission', (EU Immigration and Asylum Law and Policy Blog, 17 May 2016) <https://eumigrationlawblog.eu/dublin-is-dead -long-live-dublin-the-4-may-2016-proposal-of-the-european-commission/> accessed 19 November 2021. 
Unfortunately, this "fresh start" narrative stands in stark contrast with the substance of what is proposed - a textbook example of path-dependency. Yes, the Commission proposes to formally abolish the Dublin III Regulation and withdraws the Dublin IV Proposal. But the Proposal for an Asylum and Migration Management Regulation" (hereafter "the Asylum and Migration Management Proposal") reproduces word-for-word the Dublin III Regulation, subject to amendments drawn ... from the Dublin IV Proposal! As for the "governance framework" outlined in Articles 3-7 of the Asylum and Migration Management Proposal, it's a hodgepodge of declaratory provisions (e.g. Art. 3-4) and restatements of pre-existing obligations (Art. 5) which might eventually be moved to the preamble 6 , plus a few provisions purporting to authorize steps and procedures that actually require no legal basis (Art. 7). The one new item is a yearly monitoring exercise centered on a "European Asylum and Migration Management Strategy" (Art. 6). This seems as likely to make a difference as the "Mechanism for Early Warning, Preparedness and Crisis Management", introduced with much fanfare with the Dublin III Regulation and then left in the drawer before, during and after the crisis of 2015/16.

Leaving the provisions just mentioned for future commentaries - after all, fearless interpreters might still find legal substance in there - this contribution focuses on four points: the proposed amendments to Dublin, the interface between Dublin and procedures at the border, the new solidarity mechanism, and proposals concerning force majeure. Caveat emptor! It is a jungle of extremely detailed and sometimes obscure provisions: do not expect an exhaustive summary, nor firm conclusions on every point.

\section{2. "Hello Old Friend": The Dublin System's New Clothes}

To borrow from Mark Twain, reports of the death of the Dublin system have been once more greatly exaggerated. As noted, Part III of the Asylum and Migration Management Proposal (Articles 8-44) is for all intents and purposes an amended version of the Dublin III Regulation, and most of the amendments are lifted from the 2016 Dublin IV Proposal.

5 Commission, 'Proposal for a Regulation of the European Parliament and of the Council from the Commission on Asylum and Migration Management and Amending Council Directive (EC) 2003/109 and the Proposed Regulation (EU) XXX/XXX [Asylum and Migration Fund]', COM(2020)0279.

6 Council of the European Union, 'Pact on Migration and Asylum - Progress Report', document 9178/21, 8 . 
A first group of amendments concerns the responsibility criteria. Some expand the possibilities to allocate applicants based on their "meaningful links" with Member States: Article 2(g) expands the family definition to include siblings, opening new possibilities for reunification; Article 19(4) enlarges the criterion based on previous legal abode (i.e. expired residence documents); in a tip of the hat to the Wikstroem Report ${ }^{7}$, Article 20 introduces a new criterion based on prior education in a Member State.

These are welcome if limited concessions to a more "user-friendly" allocation of responsibility, and it is disheartening to witness the stiff resistance that they are meeting in Council ${ }^{8}$ or, more surprisingly, in EP quarters ${ }^{9}$. In other cases, advertised progress does not actually materialize in the proposal. The Commission has announced "streamlined" evidentiary requirements to facilitate family reunification. These would be necessary indeed: evidentiary issues have long undermined the application of the family criteria ${ }^{10}$. Unfortunately, the Commission is not proposing anything new: Article 30(6) of the Asylum and Migration Management Proposal corresponds in essence to Article 22(5) of the Dublin III Regulation.

7 European Parliament, 'Report on the Proposal for a Regulation of the European Parliament and of the Council Establishing the Criteria and Mechanisms for Determining the Member State Responsible for Examining an Application for International Protection Lodged in One of the Member States By a Third-Country National or a Stateless Person (Recast)', A8-0345/2017. For comment, see Francesco Maiani and Constantin Hruschka, 'The Report of the European Parliament on the Reform of the Dublin System: Certainly Bold, But Pragmatic?' (EU Immigration and Asylum Law and Policy Blog, 20 December 2017) <https:/eumigrat ionlawblog.eu/the-report-of-the-european-parliament-on-the-reform-of-the-dublin -system-certainly-bold-but-pragmatic/> accessed 19 November 2021.

8 General Secretariat of the Council, Note to Delegations, 'Proposal for a Regulation of the European Parliament and of the Council on Asylum and Migration Management and Amending Council Directive (EC) 2003/109 and the Proposed Regulation (EU) XXX/XXX [Asylum and Migration Fund] - Articles 1-2, 8-27 Comments From the Delegations', document 11617/21.

9 European Parliament, 'Draft Report on the Proposal for a Regulation of the European Parliament and of the Council on Asylum and Migration Management and Amending Council Directive (EC) 2003/109 and the Proposed Regulation (EU) XXX/XXX [Asylum and Migration Fund] (COM(2020)0610 - C9-0309/2020 -2020/0279(COD))', 2020/0279(COD), in particular amendments 32, 33 and 79.

10 See Francesco Maiani, 'The Protection of Family Unity in Dublin Procedures, Towards a Protection-Oriented Implementation Practice' (Centre Suisse pour la Défense des Droits des Migrants, 2019) <https://centre-csdm.org/wp-content/ uploads/2019/10/MAIANI-Dublin-Study-CSDM-14.10.2019.pdf > accessed 19 November 2021. 
Besides, while the Commission proposes to expand the general definition of family, the opposite is true of the specific definition of family applicable to "dependent persons". Under Article 16 of the Dublin III Regulation, applicants who e.g. suffer from severe disabilities are to be kept or brought together with a care-giving parent, child or sibling residing in a Member State. Due to fears of sham marriages, spouses have been excluded and this is legally untenable and inhumane, but instead of tackling the problem the Commission proposes in Article 24 to worsen it by excluding siblings, too. The end result is paradoxical: persons needing family support the most will be deprived - for no apparent reason other than imaginary fears of "abuses" - of the benefits of enlarged reunification possibilities. "[H]uman and humane", indeed.

The fight against secondary movements inspires most of the other amendments to the criteria. In particular, Article 21 of the Proposal maintains and extends the much-contested criterion of irregular entry while clarifying that it applies also to persons disembarked after a search and rescue (SAR) operation. Unsurprisingly, this is proving controversial ${ }^{11}$. The Commission also proposes that unaccompanied children be transferred to the first Member State where they applied if no family criterion is applicable (Article 15(5)). This would overturn the MA judgment of the $\mathrm{ECJ}^{12}$ whereby in such cases the asylum claim must be examined in the State where the child last applied and is present. It's not a technical fine point: while the case-law of the ECJ is calculated to spare children the trauma of a transfer, the proposed amendment would subject them again to the rigours of Dublin.

Again to discourage secondary movements, the Commission proposes - as in 2016 - a second group of amendments: new obligations for the applicants (Articles 9-10). Applicants must in principle apply in the Member State of first entry, remain in that State for the duration of the Dublin procedure and, post-transfer, remain in the State responsible. Moving to the "wrong" State entails losing the benefits of the Reception Conditions Directive, subject to "the need to ensure a standard of living in accordance with" the Charter. It is debatable whether this is a much lesser standard

11 General Secretariat of the Council, Note to Delegations, 'Proposal for a Regulation of the European Parliament and of the Council on Asylum and Migration Management and Amending Council Directive (EC) 2003/109 and the Proposed Regulation (EU) XXX/XXX [Asylum and Migration Fund] - Articles 1-2, 8-27 Comments From the Delegations', document 11617/21, 6, 12, 62,73 and 97.

12 CJEU, MA, BT and DA $v$ Secretary of State of the Home Department, C-648/11, ECLI:EU:C:2013:367, [2013]. 
of reception. More importantly: as reception conditions in line with the Directive are seldom guaranteed in several frontline Member States, the prospect of being treated "in accordance with the Charter" elsewhere will hardly dissuade applicants from moving on.

The 2016 Proposal foresaw, as further punishment, the mandatory application of accelerated procedures to "secondary movers". This rule disappears from the Asylum and Migration Management Proposal, but it remains in Article 40(1)(g) of the 2016 Proposal for an Asylum Procedures Regulation ${ }^{13}$. Furthermore, the Commission proposes deleting Article 18(2) of the Dublin III Regulation, i.e. the guarantee that persons transferred back to a State that has meanwhile discontinued or rejected their application will have their case reopened, or a remedy available. This is a dangerous invitation to Member States to reintroduce "discontinuation" practices that the Commission itself had once condemned as incompatible with effective access to status determination ${ }^{14}$.

To facilitate responsibility-determination, the Proposal further obliges applicants to submit relevant information before or at the Dublin interview. Late submissions are not to be considered. Fairness would demand that justified delays be excused. Besides, it is also proposed to repeal Article $7(3)$ of the Dublin III Regulation, whereby authorities must take into account evidence of family ties even if produced late in the process. All in all, then, the Proposal would make proof of family ties harder, not easier as the Commission claims.

A final group of amendments concern the details of the Dublin procedure, and might prove the most important in practice.

- Some "streamline" the process, e.g. with shorter deadlines (e.g. Article 29(1)) and a simplified take back procedure (Article 31). Controversially, the Commission proposes again to reduce the scope of appeals against transfers to issues of ill-treatment and misapplication of the family criteria (Article 33). This may perhaps prove acceptable to the ECJ in light of its old Abdullahi case-law ${ }^{15}$. However, it contravenes Article 13 ECHR, which demands an effective remedy for the violation of any Convention right.

13 Commission, 'Proposal for a Regulation of the European Parliament and of the Council Establishing a Common Procedure for International Protection in the Union and Repealing Directive 2013/32/EU', COM(2016)467.

14 CJEU, Commission of the European Communities $v$ Hellenic Republic, C-130/08, ECLI:EU:C:2008:584 [2008].

15 CJEU, Shamso Abdullahi v Bundesasylamt, C-394/12, ECLI:EU:C:2013:813, [2013]. 
- Other procedural amendments aim to make it harder for applicants to evade transfers. At present, if a transferee absconds for 18 months, the transfer is cancelled and the transferring State becomes responsible. Article 35(2) of the Proposal allows the transferring State to "stop the clock" if the applicant absconds, and to resume the transfer as soon as he reappears.

- A number of amendments make responsibility more "stable" once assigned, although not as "permanent" as the 2016 Proposal would have made it. Under Article 27 of the Proposal, the responsibility of a State will only cease if the applicant has left the Dublin area in compliance with a return decision. More importantly, under Article 26 the responsible State will have to take back even persons to whom it has granted protection. This would be a significant extension of the scope of the Dublin system, and would "lock" applicants in the responsible State even more firmly and more durably. Perhaps by way of compensation, the Commission proposes that beneficiaries of international protection obtain "long-term status" - and thus mobility rights - after three years of residence instead of five. However, given that it is "very difficult in practice ${ }^{16 "}$ to exercise such rights, the compensation seems more theoretical than effective and a far cry from a system of free movement capable of offsetting the rigidities of Dublin.

These are, in short, the key amendments to the Dublin rules that are foreseen in the proposal. While it's easy enough to comment on each individually, it is more difficult to forecast their aggregate impact. Will they - to paraphrase the Commission - "improv[e] the chances of integration" and reduce "unauthorised movements" (recital 13), and help closing "the existing implementation gap" 17 ? Probably not, as none of them strays very far from the rules applying currently.

Taken together, however, they might well aggravate the distributive imbalances caused by the Dublin system. Dublin "locks in" the responsibilities of the States that receive most applications - traditional destinations such as Germany or border States such as Italy - leaving the other Member

16 Commission, 'Report to the European Parliament and the Council on the Implementation of Directive 2003/109/EC Concerning the Status of Third-Country Nationals Who Are Long-term Residents', COM(2019)161.

17 Commission, 'Communication to the European Parliament, the Council, the European Economic and Social Committee and the Committee of the Regions, on a New Pact on Migration and Asylum', COM(2020)609. 
States relatively unaffected ${ }^{18}$. Apart from possible distributive impacts of the revised criteria and of the new obligations imposed on applicants, first application States will certainly be disadvantaged by the combination of shortened deadlines, security screenings (see below), streamlined take backs, and "stable" responsibility extending to beneficiaries of protection. Under the "new Dublin rules" - sorry for the oxymoron! - effective solidarity will become more necessary than ever.

\section{Border Procedures and Dublin}

Building on the current hotspot approach, the Proposals for a Screening Regulation ${ }^{19}$ and for an Asylum Procedures Regulation ${ }^{20}$ outline a supposedly new "pre-entry" phase. This is examined in-depth in a separate chapter by Lyra Jakuleviciene, but the interface with infra-EU allocation deserves mention here.

In a nutshell, persons irregularly crossing the border will according to this Proposal be screened for the purpose of identification, health and security checks, and registration in Eurodac. Protection applicants may then be channelled to "border procedures" in a broad range of situations. This will be mandatory if the applicant: (a) attempts to mislead the authorities; (b) can be considered, based on "serious reasons", "a danger to the national security or public order of the Member States"; (c) comes from a State whose nationals have a low Union-wide recognition rate (Article 41(3) of the Asylum Procedure Proposal).

The purpose of the border procedure is to assess applications "without authorising the applicant's entry into the Member State's territory" 21. Therefore, it might have seemed logical that applicants subjected to it be excluded from the Dublin system - as is the case, ordinarily, for relocations (see below). Not so: under Article 41(7) of the Proposal, Member States

18 Commission, 'Communication to the European Parliament, the Council, the European Economic and Social Committee and the Committee of the Regions, on a New Pact on Migration and Asylum', $\operatorname{COM}(2020) 609,6$.

19 Commission, 'Proposal for a Regulation of the European Parliament and of the Council: Introducing a Screening of Third Country Nationals at the External Borders and Amending Regulations (EC) No 767/2008, (EU) 2017/2226, (EU) 2018/1240 and (EU) 2019/817', COD(2020)0278.

20 Commission, 'Amended Proposal for a Regulation of the European Parliament and of the Council Establishing a Common Procedure for International Protection in the Union and Repealing Directive 2013/32/EU', COD(2016)0224.

21 Ibid, 4. 
may apply Dublin in the context of border procedures. This weakens the idea of "seamless procedures at the border" somewhat. However, from the standpoint of both applicants and border States, it is better than a watertight exclusion. Indeed, applicants may still benefit from the criteria based on "meaningful links", and border States are not "stuck with the caseload" so to speak. I would normally have qualms about giving Member States discretion in choosing whether Dublin rules apply or not. But as it happens, Member States who receive an asylum application already enjoy that discretion under the so-called "sovereignty clause", i.e. Article 17(1) of the Dublin III Regulation. Nota bene: according to well-settled case-law, in exercising discretion under the sovereignty clause Member States apply EU Law and must therefore observe the Charter ${ }^{22}$. The same principle must certainly apply under the proposed Article 41(7).

The only true exclusion from the Dublin system is set out in Article 8(4) of the Asylum and Migration Management Proposal. Under this provision, Member States must carry out a security check of all applicants as part of the pre-entry screening and/or after the application is filed. If "there are reasonable grounds to consider the applicant a danger to national security or public order" of the determining State, the other criteria are bypassed and that State becomes responsible. Attentive readers will note that the wording of Article 8(4), which refers to "reasonable grounds" to consider the applicant a danger for the determining State, differs from that of Article 41(3) of the Asylum Procedure Proposal, which instead refers to "serious grounds" to consider the applicant a danger for the Member States as a whole. It is therefore unclear whether the security grounds to "screen out" an applicant from Dublin are coextensive with the security grounds making a border procedure mandatory ${ }^{23}$. Be that as it may, a broad application of Article 8(4) would be undesirable, as it would entail a large-scale exclusion from the guarantees that applicants derive from the Dublin system. The risk is moderate however: by applying Article 8(4) widely, Member States would be increasing their own share of responsibilities under the system. As twenty-five years of Dublin practice attest, this is unlikely to happen.

22 CJEU, N. S. and Others, C-411/10, ECLI:EU:C:2011:865, [2011].

23 For an attempt to partially bridge the gap, see Council of the European Union, 'Note on Draft Regulation of the European Parliament and of the Council, on Asylum and Migration Management and Amending Council Directive (EC) 2003/109 and the Proposed Regulation (EU) XXX/XXX [Asylum and Migration Fund]', document 10450/21, 10. 


\section{4. "Mandatory" and "Flexible" Solidarity under the New Mechanism}

For the aspects examined so far, the Asylum and Migration Management Proposal does not differ significantly from the 2016 Dublin IV Proposal, which did not itself fundamentally depart from existing rules and which, may I add, went down in flames in inter- and intra-institutional negotiations. Any hopes of a "fresh start", then, are left for the new solidarity mechanism.

Unfortunately, solidarity is a difficult subject for the EU: financial support has hitherto been a mere fraction of Member State expenditure in the field ${ }^{24}$; operational cooperation has proved useful but cannot tackle all the relevant aspects of the unequal distribution of responsibilities among Member States; relocations have proved extremely beneficial for thousands of applicants, but are intrinsically complex operations and have also proven politically divisive. This, along with the heavy bureaucracy involved, an inadequate scope of application, and the failure to systematically gain the trust and willing cooperation of the applicants, has severely undermined their application ${ }^{25}$ and further condemned them to be small scale affairs relative to the realities and needs on the ground. The same goes a fortiori for ad hoc initiatives - such as those that followed SAR operations over the last two years ${ }^{26}$ - which furthermore lack the predictability that is necessary for sharing responsibilities effectively. To reiterate what the Commission stated, there is currently "no effective solidarity mechanism in place".

Perhaps most importantly, the EU has hitherto been incapable of accurately gauging the distributive asymmetries on the ground, to articulate a clear doctrine guiding the key determinations of "how much solidarity"

24 Iris Goldner Lang, 'Financial Framework' in Philippe De Bruycker, Marie De Somer and Jean-Louis De Brouwer (eds), From Tampere 20 to Tampere 2.0: Towards a New European Consensus on Migration (European Policy Centre 2019), 17.

25 For an in-depth assessment see European Parliament, 'Study on the Implementation of the 2015 Council Decisions Establishing Provisional Measures in the Area of International Protection for the Benefit of Italy and of Greece' (PE583132, 2017). See also CJEU, Commission v Poland (Temporary Mechanism for the Relocation of Applicants for International Protection), C-715/17, ECLI:EU:C:2020:257, [2020].

26 Eleonora Frasca and Francesco Luigi Gatta, 'The Malta Declaration on Search \& Rescue, Disembarkation and Relocation: Much Ado About Nothing' (EU Immigration and Asylum Law and Policy Blog, 3 March 2020) <https://eumigrationlawblo g.eu/the-malta-declaration-on-search-rescue-disembarkation-and-relocation-much -ado-about-nothing/> accessed 19 November 2021. 
and "what kind(s) of solidarity", and to define commensurate redistributive targets on this basis ${ }^{27}$. What better time than now?

Alas, the opportunity to elaborate a solidarity doctrine for the CEAS has been completely missed. Conceptually, the New Pact does not go much farther than platitudes such as "[s]olidarity implies that all Member States should contribute 28 ". As Daniel Thym aptly observed ${ }^{29}$, "pragmatism" is the driving force behind the Proposal: the Commission starts from a familiar basis - relocations - and tweaks it in ways designed to convince stakeholders that solidarity becomes "compulsory" or "flexible" as required to suit their policy preferences ${ }^{30}$. It's a complicated arrangement and I will only describe it in broad strokes, leaving the crucial dimensions of financial solidarity and operational cooperation for Iris Goldner Lang and Lilian Tsourdi to examine in their respective chapters.

The mechanism operates in three "modes". In its basic mode, it is to replace ad hoc solidarity initiatives following SAR disembarkations (Articles 47-49 of the Asylum and Migration Management Proposal):

- The Commission determines, in its yearly Migration Management Report, whether a State is faced with "recurring arrivals" following SAR operations and determines the needs in terms of relocations and other contributions (capacity building, operational support proper, cooperation with third States).

- The Member States are "invited" to notify the "contributions they intend to make". If offers are sufficient, the Commission combines them and formally adopts a "solidarity pool". If not, it adopts an imple-

27 Lilian Tsourdi, 'EU Agencies' in Philippe De Bruycker, Marie De Somer and Jean-Louis De Brouwer (eds), From Tampere 20 to Tampere 2.0: Towards a New European Consensus on Migration (European Policy Centre 2019), 34; Francesco Maiani, 'Responsibility Allocation and Solidarity' in Philippe De Bruycker, Marie De Somer and Jean-Louis De Brouwer (eds), From Tampere 20 to Tampere 2.0: Towards a New European Consensus on Migration (European Policy Centre 2019), 107.

28 Commission, 'Communication to the European Parliament, the Council, the European Economic and Social Committee and the Committee of the Regions, on a New Pact on Migration and Asylum', COM(2020)609.

29 See Daniel Thym's chapter 'Never-Ending Story? Political Dynamics, Legislative Uncertainties, and Practical Drawbacks of the "New" Pact on Migration and Asylum' in this volume.

30 See also Sergio Carrera, 'Whose Pact? The Cognitive Dimensions of the New EU Pact on Migration and Asylum' (CEPS Policy Insights, September 2020), 2-3 $<$ www.ceps.eu/wp-content/uploads/2020/09/PI2020-22-New-EU-Pact-on-Migratio n-and-Asylum.pdf $>$ accessed 19 November 2021. 
menting act summarizing relocation targets for each Member State and other contributions as offered by them. Member States may react by offering other contributions instead of relocations, provided that this is "proportional" - one wonders how the Commission will tally e.g. training programs for Libyan coastguards with relocation places.

- If the relocations offered fall $30 \%$ short of the target indicated by the Commission, a "critical mass correction mechanism ${ }^{31}$ " will apply: each Member State will be obliged to meet at least $50 \%$ of the quota of relocations indicated by the Commission. However, and this is the new idea offered by the Commission to bring relocation-skeptics onboard, Member States may discharge their duties by offering "return sponsorships" instead of relocations: the "sponsor" Member State commits to support the benefitting Member State to return a person and, if the return is not carried out within eight months, to accept her on its territory.

Peeling the onion, it would appear that we are dealing with "half-compulsory" solidarity in terms of relocations. Indeed, under Article 48(2) of the Proposal Member States are obliged to cover at least 50\% of the relocation needs set by the Commission through relocations or sponsorships, and the rest with other contributions.

Be that as it may, after the "solidarity pool" is established and the benefitting Member State requests its activation, relocations can start:

- The eligible persons are those who applied for protection in the benefitting State, with the exclusion of those who are subject to border procedures (Article 45(1)(a)). Also excluded are those whom Dublin criteria based on "meaningful links" - family, abode, diplomas - assign to the benefitting State (Article 57(3)). These rules imply that the benefitting State must carry out identification, screening for border procedures and a first (simplified?) Dublin procedure before it can declare an applicant eligible for relocation. Persons eligible for return sponsorship are "illegally staying third-country nationals" (Article 45(1)(b)).

- The eligible persons are identified, placed on a list, and matched to Member States based on "meaningful links". The transfer can only be refused by the State of relocation on security grounds (Article $57(2)(6)$ and (7)), and otherwise follows the modalities of Dublin transfers in

31 Commission, 'New Pact on Migration and Asylum. Questions and Answers' (Press corner, 23 September 2021) <https://ec.europa.eu/commission/presscor ner/detail/en/qanda_20_1707> accessed 19 November 2021. 
almost all respects (e.g. deadlines, notification, appeals). However, contrary to what happens under Dublin, missing the deadline for transfer does not entail that the relocation is cancelled (see Article 57(10)).

- After the transfer, applicants will be directly admitted to the asylum procedure only if it has been previously established that the benefitting State would have been responsible under criteria other than those based on "meaningful links" (Article 58(3)). In all the other cases, the State of relocation will have to run a further Dublin procedure and, if necessary, transfer again the hapless applicant to the State responsible (see Article 58(2)). As for persons subjected to return sponsorship, the State of relocation will pick up the application of the Return Directive where the benefitting State left off (or so I read Article 58(5)) ${ }^{32}$.

If the Commission concludes that a Member State is under "migratory pressure", at the request of the concerned State or of its own motion (Article 50), the mechanism operates as described above except for one main point: beneficiaries of protection also become eligible for relocation (Article 51(3)). Thankfully, they must consent thereto and are automatically granted the same status in the relocation State (see Articles 57(3) and $58(4))$.

If the Commission concludes that a Member State is confronted with a "crisis", rules change further (see Article 2 of the Proposal for a Migration and Asylum Crisis Regulation):

- Applicants subject to the border procedure and persons "having entered irregularly" also become eligible for relocation. These persons may then undergo a border procedure post-relocation (see Article 41(1) and (8) of the Proposal for an Asylum Procedures Regulation).

- Persons subject to return sponsorship are transferred to the sponsor State if their removal does not occur within four - instead of eight months.

- Other contributions are excluded from the palette of contributions available to the other Member States (Article 2(1)): it has to be either relocation or return sponsorship.

- The procedure is faster, with shorter deadlines.

32 See also European Council on Refugees and Exiles, 'ECRE Comments on the Commission Proposal for a Regulation on Asylum and Migration Management' (ECRE, February 2021), $18<$ https://ecre.org/wp-content/uploads/2021/03/ECRE-C omments-RAMM.pdf $>$ accessed 19 November 2021. 
It is an understatement to say that the mechanism is complex, and its exact implications are unclear. For the time being, I would make four general comments.

- To begin with, it is not self-evident that this is a good "insurance scheme" for its intended beneficiaries. As noted, the system only guarantees that $50 \%$ of the relocation needs of a State will be met. Furthermore, there are hidden costs: in "SAR" and "pressure" modes, the benefitting State has to screen the applicant, register the application, and assess whether border procedures or (some) Dublin criteria apply before it can channel the applicant to relocation. It is unclear whether a 500 lump sum is enough to offset these costs (see Article 79 of the Asylum and Migration Management Proposal). Besides, in a crisis situation, these preliminary steps might make relocation impractical think of the Greek registration backlog in 2015/6. Perhaps, extending relocation to persons "having entered irregularly" when the mechanism is in "crisis mode" is meant precisely to take care of this. Similar observations apply to return sponsorship. Under Article 55(4) of the Asylum and Migration Management Proposal, the support offered by the sponsor to the benefitting State can be rather low key (e.g. "counselling") and there seems to be no guarantee that the benefitting State will be effectively relieved of the political, administrative and financial costs associated to return. Moving from costs to risks, it is clear that the benefitting State bears all the risks of non implementation - in other words, if the system grinds to a halt or breaks down, it will be Moria all over again. In light of past experience, one can only agree with Thomas Gammelthoft-Hansen that relying on the mechanism to provide effective solidarity would be a "big gamble 33 ". Other aspects examined below - the vast margins of discretion left to the Commission, and the easy backdoor opened by the force majeure provisions - appear to further reduce reliability and predictability.

- Indeed, as just noted the mechanism gives the Commission practically unlimited discretion at all critical junctures. The Commission will determine whether a Member States is confronted to "recurring arrivals", "pressure" or a "crisis". It will do so under definitions so open-textured, and criteria so numerous, that it will be basically the master of its own

33 Lauren Chadwich and Lillo Montalto Monella, 'What Is the EU's New Migration Pact and How Has It Been Received?' (Euronews, 25 June 2020) <www.euronews.c om/2020/09/24/what-is-the-eu-s-new-migration-pact-and-how-has-it-been-received > accessed 19 November 2021. 
determinations (Article 50 of the Asylum and Migration Management Proposal). The Commission will determine unilaterally relocation and operational solidarity needs. Finally, the Commission will determine - we do not know how - if "other contributions" are proportional to relocation needs. Other than in the most clear-cut situations, there is no way that anyone can predict how the system will be applied ${ }^{34}$.

- Furthermore, the mechanism reflects a powerful fixation with and unshakable faith in heavy bureaucracy. Protection applicants may undergo up to three "responsibility determination" procedures and two transfers before finally landing in an asylum procedure: Dublin "screening" in the first State, matching, relocation, full Dublin procedure in the relocation State, then transfer. And this is a system that should not "compromise the objective of the rapid processing of applications" (recital 34)! Decidedly, the idea that in order to improve the CEAS it is above all necessary to suppress unnecessary delays and coercion $^{35}$ has not made a strong impression on the mind of the drafters. The same remark applies mutatis mutandis to return sponsorships: whatever the benefits in terms of solidarity and of heightened return "muscle" vis-à-vis countries of origin and transit, one wonders if it is very cost-effective or humane to drag a person from Member State to Member State so that they can each try their hand at expelling her.

- Lastly and relatedly, applicants and other persons otherwise concerned by the relocation system are given no voice. They can be "matched", transferred, re-transferred, but subject to few exceptions their aspirations and intentions remain legally irrelevant. In this regard, the "New Pact" is as old school as it gets: it sticks strictly to the "no choice" taboo on which Dublin is built. What little recognition of applicants' actorness had been made in the Wikstroem Report ${ }^{36}$ is gone. Objectifying migrants is not only incompatible with the claim that the approach taken is "human and humane". It might prove fatal to the administrative efficiency so cherished by the Commission. Indeed, failure to

34 For a similar comment, see European Parliament, 'Study Report on The European Commission's New Pact on Migration and Asylum, Horizontal Substitute Impact Assessment' (European Parliamentary Research Service PE694.210, August 2021), 131.

35 European Parliament, 'New Approaches, Alternative Avenues and Means of Access to Asylum Procedures for Persons Seeking International Protection' (requested by the LIBE Committee, PE509989, 2014), 9.

36 Maiani and Hruschka, 'The Report of the European Parliament on the Reform of the Dublin System: Certainly Bold, But Pragmatic?' (n 7). 
engage applicants is arguably the key factor in the immutably dismal performance of the Dublin system ${ }^{37}$. Why should it be any different under this solidarity mechanism?

\section{Framing Force Majeure or Inviting Defection?}

In addition to addressing "crisis" situations, the Proposal for a Migration and Asylum Crisis Regulation ${ }^{38}$ includes separate provisions on force majeure.

Thereunder, any Member State may unilaterally declare that it is faced with a situation making it "impossible" to comply with selected CEAS rules, and thus obtain the right - subject to mere notification - to derogate from them. Member States may obtain in this way longer Dublin deadlines, or even be exempted from the obligation to accept transfers and be liberated from responsibilities if the suspension goes on more than a year (Article 8). Furthermore, States may obtain a six-month suspension of their duties under the solidarity mechanism (Article 9).

The inclusion of this proposal in the Pact - possibly an attempt to further placate Member States averse to European solidarity? - beggars belief. Legally speaking, the whole construction is redundant: under the case-law of the ECJ, Member States may derogate from any rule of EU Law if confronted with a genuine case of force majeure ${ }^{39}$. However, putting this black on white amounts to inviting (and legalizing) defection in the name of unilaterally declared reasons of national interest ${ }^{40}$, as if Member States

37 Maiani, 'Responsibility Allocation and Solidarity' (n 27), 112. For fresh figures see: European Council on Refugees and Exiles, 'The Implementation of the Dublin III Regulation in 2020' (Asylum Information Database, September 2021) $<$ https://asylumineurope.org/wp-content/uploads/2021/09/AIDA_Dublin-Update -2020.pdf $>$ accessed 19 November 2021.

38 Commission, 'Proposal for a Regulation of the European Parliament and of the Council Addressing Situations of Crisis and Force Majeure in the Field of Migration and Asylum', COD (2020)0277.

39 CJEU, Commission v Italy, C-101/84, ECLI:EU:C:1985:330, [1985]. See also, in relation to Article 72 TFEU specifically: CJEU, Commission v Poland (Temporary Mechanism for the Relocation of Applicants for International Protection), C-715/17, ECLI:EU:C:2020:257 [2020], para 147.

40 See also: European Council on Refugees and Exiles, 'Comments on the Commission Proposal for a Regulation Addressing Situations of Crisis and Force Majeure in the Field of Migration and Asylum' (ECRE, February 2021), $18<$ https://ecre 
needed this kind of encouragement ${ }^{41}$. The only conceivable object of rules of this kind might have been to proceduralize force majeure and subject any derogations to prior authorization by the Commission. However, there is nothing of the kind in the Proposal. The end result is paradoxical: while Member States are (in theory 42 !) subject to Commission supervision when they conclude arrangements aiming to facilitate the implementation of Dublin rules, a mere notification will be enough to authorize them to unilaterally tear a hole in the fabric of "solidarity" and "responsibility" so painstakingly - if not felicitously - woven in the Pact.

\section{Concluding Comments}

We should have taken Commissioner Ylva Johansson at her word when she said that there would be no "Hoorays" 43 for the new proposals. Past the avalanche of adjectives, promises and fancy administrative monikers hurled at the hapless reader - "faster, seamless migration processes"; "prevent the recurrence of events such as those seen in Moria"; "critical mass correction mechanism" - one cannot fail to see that the "fresh start" is essentially an exercise in repackaging.

.org/wp-content/uploads/2021/03/ECRE-Comments-COM2020-613-V2-2.pdf> accessed 19 November 2021.

41 The crisis developing at the EU borders with Belarus constitutes a prime example, see: European Council on Refugees and Exiles, 'Legal Note 11: Extraordinary Responses: Legislative Changes in Lithuania' (ECRE, 2021) <https://ecre.org/wp-c ontent/uploads/2021/09/Legal-Note-11.pdf > accessed 19 November 2021. On the belated and ambiguous reaction of the Commission so far, see: Josephine Joly and Shona Murray, 'EU Executive Summons Polish, Lithuanian, Latvian Ambassadors Over Belarus Border Crisis' (Euronews, 15 October 2021) <www.euronews.com/2 021/10/15/eu-executive-summons-polish-lithuanian-latvian-ambassadors-over-b elarus-border-crisis $>$ accessed 19 November 2021. And: Commission, 'Statement by President von der Leyen On the Situation at the Border Between Poland and Belarus' (Press corner, 8 November 2021) <https://ec.europa.eu/commission/press corner/detail/en/statement_21_5867> accessed 19 November 2021.

42 Vinzent Vogt, 'Family Life Temporarily Not Available - Bilateral Limits on Family Unity Within the Dublin-System' (Verfassungsblog, 13 July 2017) <https://verfass ungsblog.de/family-life-temporarily-not-available-bilateral-limits-on-family-unity -within-the-dublin-system/> accessed 19 November 2021.

43 Michael Peel and Sam Fleming, 'EU to Step Up Pressure Over Migrant Returns' (Financial Times, 18 September 2020) <www.ft.com/content/05837dfe-1739-4aae-9 a37-aee94f588327> accessed 19 November 2021. 
On responsibility-allocation and solidarity, the basic idea is one that the Commission incessantly returns to since 200744: keep Dublin and "correct" it through solidarity schemes. I do sympathize to an extent: realizing a fair balance of responsibilities by "sharing people" has always seemed to me impracticable and undesirable ${ }^{45}$. Still, one would have expected that the abject failure of the Dublin system, the collapse of mutual trust in the CEAS, the meagre results obtained in the field of solidarity (per the Commission's own appraisal) would have pushed it to bring something new to the table.

Instead, what we have is a slightly milder ${ }^{46}$ version of the Dublin IV Proposal - the ultimate clunker in the history of Commission proposals - and an ultra-bureaucratic mechanism for relocation, with the dubious addition of return sponsorships and force majeure provisions. The basic tenets of infra-EU allocation remain the same - "no choice", first entry and none of the structural flaws that doomed current schemes to failure is fundamentally tackled ${ }^{47}$ : solidarity is beefed-up but appears too unreliable and fuzzy to generate trust - including to the Member States that are most interested in $\mathrm{it}^{48}$; there are interesting steps forward on "genuine links", alas strongly resisted by some Member States in Council and even in the $\mathrm{EP}$, but otherwise no sustained attempt to positively engage applicants; administrative complexity and coercive transfers reign on.

Pragmatism, to quote again Daniel Thym ${ }^{49}$, is no sin. It is even expected of the Commission. This, however, is a study in path-dependency. Instead of moving the discussion forward, it merely takes it roundabout in a seemingly endless loop. Granted, by defending the status quo, wrapping it in shiny new paper, and making limited concessions to key policy actors, the Commission may eventually carry its proposals through in one form or another. This will matter little, however. Without substantial corrections,

44 Commission, 'Green Paper on the Future Common European Asylum System', $\operatorname{COM}(2007) 301,10$.

45 Francesco Maiani, 'The Reform of the Dublin System and the Dystopia of "Sharing People"' (2017) 24(5) Maastricht Journal of European and Comparative Law 622-645.

46 For an analysis of the Dublin IV Proposal see: Hruschka, 'Dublin Is Dead! Long Live Dublin! The 4 May 2016 Proposal of the European Commission' (n 4).

47 Maiani, 'Responsibility Allocation and Solidarity' (n 27), 107.

48 La Moncloa, 'New Pact on Migration and Asylum: Comments by Greece, Italy, Malta and Spain' (La Moncloa, Paper 251120/2020, 2020) <www.lamoncloa.gob.e s/presidente/actividades/Documents/2020/251120-Non\%20paper\%20Pacto\%20Mi gratorio.pdf $>$ accessed 19 November 2021.

49 Thym (n 29). 
without true and workable innovations, the "new" Pact will be a reform only in name. It will leave the CEAS and its inhabitants in their current straits and fail to solve even just one of its structural flaws, while degrading legal protection in many respects.

It might be best to leave the reform of the Dublin Regulation alone, or any other legislative grand scheme, and to invest elsewhere what political and administrative resources the EU and its Member States still have: in the gradual deployment of feasible forms of solidarity, and in the indispensable task of securing the full implementation of EU standards and rules as they stand, in line with the values and principles enshrined in the Treaty and the Charter. Working towards this modest but worthwhile objective should keep us all - institutions, academia, civil society - busy for many years to come. 